Crop Breeding and Applied Biotechnology 15: 100-105, 2015

Brazilian Society of Plant Breeding. Printed in Brazil

NOTE

http://dx.doi.org/10.1590/1984-70332015v15n2n18

\title{
Brazilian biodiversity for ornamental use and conservation
}

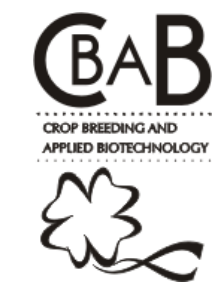

\author{
Roberto Romão ${ }^{1 *}$, Gustavo Martinelli ${ }^{2}$, Iara Crepaldi ${ }^{1}$ and Juan Bautista Martinez-Laborde ${ }^{3}$
}

Submitted 15 July 2014

Accepted 03 November 2014

\begin{abstract}
The exuberance of Brazilian flora has caused admiration since the arrival of the first navigators. Fifteen to twenty percent of plant species estimated for the planet are found in this country. Plant genetic resources are part of biodiversity with potential for use by human populations, and are linked to the culture of the people, establishing the traditional use or enabling an innovative use. In Brazil, the landscape architect Roberto Burle Marx was a pioneer in collecting, using, valuing and preserving native species that have been admired since the $16^{\text {th }}$ century, although they were neglected in the following centuries due to the valuation of ornamental plants from Europe. Between 1930 and 1960, he carried out landscaping projects that became emblematic for the development of landscaping in the $20^{\text {th }}$ century. The analysis of the trajectory of the landscape architect, the 22 projects he carried out during that period, as well as the genebank structured by him, reveal significant numbers in terms of conservation.
\end{abstract}

Key words: Plant genetic resources, landscaping, genetic innovation, germplasm.

\section{INTRODUCTION}

Brazil presents between 10 and $20 \%$ of the estimated plant species on the planet. Therefore, thanks to this abundant diversity, it has enormous potential and comparative advantages in the area of species for ornamental use. The landscape architect Roberto Burle Marx (1909-1994) gave great incentive to the use of those species (Cavalcanti and El-Dahdah 2009). Burle Marx was a Brazilian conservationist and the first one to massively use native species. Outstanding among the species that are representative for the families most used in his projects, and that are preserved at the "Sítio Roberto Burle Marx", are species of Arecaceae, like Euterpe oleraceae, which has been used 1,418 times in projects (Figure 1A), and Copernicia macroglossa (Figure 1B), as well as species of Araceae, like Philodendron undulatum, which has been used 8,414 times in projects (Figure 1C).

Biodiversity, according to the text of the International Convention on Biodiversity (CDB 2000), is the variability of living organisms of all origins, including, among others, the terrestrial, marine and freshwater ecosystems, and the environmental complexes they are part of. Intra- and interspecific diversity and the diversity of ecosystems are also included. Within this definition, it is important to point out the relevance of culture, regarding the body of knowledge associated to the use and management of biodiversity, seeing that once the cultural aspect is being observed, the biological diversity acquires a new dimension, causing plant genetic resources to gain visibility.

Plant genetic resources (PGRs), this is, the part of biodiversity that has actual or potential value, are those resources that are in some way useful to human populations, seeing that this usefulness varies according to the cultural ways of each group of people, since it is through culture that traditional and innovative uses are established.

The research of the ornamental plant sector may provide information on how native biodiversity contributes to the national development, mainly because this sector is liable to technological innovation, in the Italian sense, which aligns creativity and local resources with minimal financial input. Furthermore, it brings along additional benefits, introducing a large number of people into the productive sector, who are generally marginalized because of low schooling level and/ or because they live far from large urban centers.

Statistics show that, within the agricultural sector, the

*E-mail: romaoroberto gmail.com

2 Jardim Botânico Rio de Janeiro, CNCFLORA, 22.470-180, Rio de Janeiro, RJ, Brazil

${ }^{3}$ Universidad Politécnica de Madrid, Departamento de Biotecnología-Biología Vegetal, Escuela T.S. de Ingenieros Agrónomos, Ciudad Universitaria, 28040 Madrid, Spain 

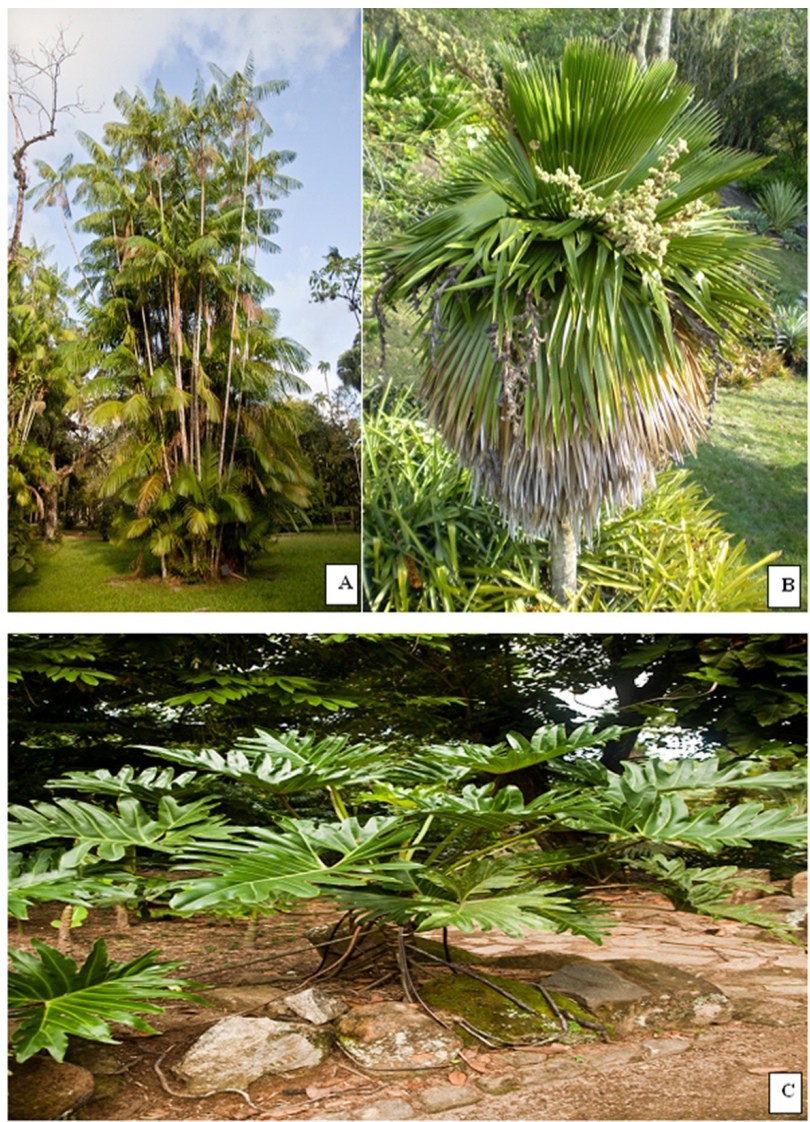

Figure 1. Species of Arecaceae, Euterpe oleracea (A) Archive Curator of Living Plant Collections at the Botanic Garden in Rio de Janeiro, RJ, photographer: André Porto; e Copernicia macroglossa (B) Photograph taken at Sítio Roberto Burle Marx, Robério Dias' personal archive. Species of Araceae, Philodendron undulatum (C) Archive Curator of Living Plant Collections at the Botanic Garden in Rio de Janeiro, RJ, Brazil. Photographer: André Porto.

flower and ornamental plant segment is among the ones that show the largest capability of rapidly including workers into the labor market. It has moved over US\$ 50 billion worldwide, and about US\$ 1 billion in Brazil. Besides, the ornamental plant seedling segment continues leading Brazilian exports, representing a relative share of $57.78 \%$ of the overall commercialization on the international market (Graziano 2002, Tay 2005).

Regarding the work carried out by Burle Marx, it is known that in order to organize his gardens in the early 1930s, the landscape architect valued, used and visualized the landscape on the basis of the diversity of the Brazilian flora. For this, samplings and basic studies of the native biodiversity were of the outmost importance. Those activities of sampling, conservation, valorization and use of native plants, which were so strongly implemented by Burle Marx, enabled the transformation of a large part of the biodiversity into plant genetic resources.

Hundreds of native species had been disdained and considered of no value until then, for several reasons: 1) for being abundant; 2) for composing the physiognomy of several biomes such as woods, fields, savannas, that are part of a rustic landscape, and therefore considered "weeds" in a pejorative meaning; 3 ) for being Brazilian, without the cultural charms of being exotic, and therefore losing the appeal of those coming from European gardens; 4) for lack of knowledge as to cultivation requirements, propagation forms, and so on.

Burle Marx, however, has solid knowledge as well as a vision of the future, and sees characteristics and potential in those disdained species, which according to the predominant viewpoint of that period are obstacles to their successful utilization. Thus, in the abundance of the species, he sees opportunities for their safe use and, through the study of their propagation, the preservation of those species. Burle Marx understands that it is possible to take advantage of the fact that those species are part of the phytophysiognomy of many Brazilian biomes, targeting a reduction of costs and work involved in the maintenance of the gardens, and during the adaptation of introduced species, besides reducing the risks of pest contamination. Thus, he uses the formerly disdained rusticity as an important characteristic for commercial use.

Moreover, it is Burle Marx who introduces the beauty of the texture, colors, shapes and architecture of so many species from so varied botanic families to Brazil and to the whole world, changing the understanding of what is exotic, which by then used to be anything that had come to the country from abroad, and now is seen as the expression of the beauty coming from native habitats throughout Brazil into the Brazilian cities.

An intense movement can be noticed hence, of native species being grown, gaining market value, and becoming subject of study and admiration.

\section{BRAZILIAN NATURE AND LANDSCAPING}

The exuberance of the Brazilian nature has caused amazement since Pero Vaz Caminha first described the newly discovered land (Filgueiras and Peixoto 2002). Later on, it would be described in countless chronicles by exploring travelers, naturalists and artists (Martins 2009).

In travelers' chronicles from the $18^{\text {th }}$ and $19^{\text {th }}$ centuries, the tropical and the Brazilian extravagance tended to be intermingled, often even seeming to be one and the same. And if on one hand there was the discovery and the amaze- 
ment, on the other there was the fear of the unknown that gripped hold of anyone who ventured into the new territory. It was in this context that initially a trend was established, and it explained the tropical diversity as a degeneration of nature, which ought to be eradicated in order to give place to the production of goods for exportation (Dean 1992).

This trend was reinforced by the first settlers in the new land, and dominated the ways of occupation of the Brazilian landscape. The notion of a degenerated nature that needed to be civilized prevailed throughout many years in the national imagery (Marx 2004). Just as the Portuguese language unified and dominated the cultural scene, this Luso-Brazilian matrix determined the relation between man and nature, and the construction of the landscape.

Regarding the concept of a garden, as created and grown by man, it is known that it was introduced in Brazil in the $17^{\text {th }}$ century, firstly by Portuguese settlers, and later on by foreigners who came to live here. It was related to an intense process of transformation of the landscape, with substitution of the native vegetation with Asian, African and European species (Freyre 2003).

The "Brazilian garden" had in its beginnings a strong Asian influence, regarding the structure and the use of materials coming from that continent, but was cosmopolitan as to the used species and their origins. At the time, the Brazilian garden had its focus on functionality rather than on esthetics, the more as it generally would be found in the backyards of family homes and orchards of religious orders.

The arrival of the Royal Family in Rio de Janeiro would produce a Europeanization of the country and the gardens, with great admiration for European plants and flowers, leading to a loss in importance of tropical species, including native ones, as well as already acclimated ones (Marx 2004).

Although native species were used in gardens in family backyards, and some native elements were also found in the first experiences with public gardening, most of the used plants were imported, and even a few of the used native Brazilian species came from Europe (Flemming 1996).

In order to use native species in a systematic way, it was necessary to accomplish a laborious domestication process, which was initiated by Roberto Burle Marx through sampling expeditions to the outskirts of the city of Rio de Janeiro. It is important to emphasize that Burle Marx was an autodidact regarding botany, seeing that his education had been in arts and humanities. He started his work as a landscape architect, which was marked by the discovery of the Brazilian flora, when he read the novel Os Sertões by Euclides da Cunha, which incited him to research the plants of the caatinga.
It was then, in the 1930s, in Recife, that he developed the first genuinely Brazilian landscaping projects, massively using species from native biodiversity, especially species from the Amazon region, from the caatinga, and from the coastal tablelands (Frota 2009).

As he began his activity as a landscape architect, he felt the urge to research the native flora and, for this, he undertook expeditions to several parts of Brazil with the intention to collect species of interest for landscaping. This gave him the opportunity to increase the number of species he had access to, and his experiments cultivating these plants allowed him to understand their forms of propagation, their ecologies, as well as other aspects (Dias 2011).

The way he carried out his activities led him to spontaneously work with plant genetic resources (PGRs), this is, the part of biodiversity that has actual or potential value (Giacometti and Goedert 1989, Giacometti 1993).

In order to assemble his plant collection - first at the small farm owned by his family in the Leme neighborhood in Rio de Janeiro, and later on, in 1949, in Barra de Guaratiba, at the farm called "Sítio de Santo Antonio" (Dourado 2009) - he started working in a more systematic way, regarding the sampling and conservation, as well as the domestication and propagation. For this, although in a somewhat empirical way, he carried out the stages of research traditionally used for genetic resources, which are: sampling/introduction, multiplication, characterization, evaluation, conservation and use (Hawkes 1982, Valls 1988).

Countless projects were carried out during the studied period (1930-1960), twenty-two of which have been analyzed in this article. The trajectory that was revealed had its beginnings in Recife - Pernambuco (1934-1937), and culminated in Rio de Janeiro (1960) with the "Aterro do Flamengo", the largest project carried out by the landscape architect.

One of the outstanding characteristics of the studied projects was the variety of types, including family home gardens, public parks, gardens for housing estates, gardens for private clubs, and public green areas (Table 1). Most of those projects were developed in urban areas, but there are some in rural areas, including projects where all elements are defined, as well as those that only preserve the definition of trees.

It was thanks to Burle Marx that many native and introduced species with ornamental potential were first cultivated (Lorenzi and Mello Filho 2001). After having properly figured out the requirements of the plants and their form of reproduction, he could choose them to be used in landscaping projects or to be kept in the collection at the "Sítio". 
Table 1. List of projects, year, city, state, and number of used species per project

\begin{tabular}{|c|c|c|c|c|}
\hline Project & Year & City & State & Number of Species* \\
\hline Casa Forte square (trees) & 1935 & Recife & $\mathrm{PE}$ & 14 \\
\hline Derby spare & 1936 & Recife & $\mathrm{PE}$ & 86 \\
\hline Ministry of Education and Health & 1938 & Rio de Janeiro & $\mathrm{RJ}$ & 85 \\
\hline Residence of Juscelino Kubitschek & 1943 & Belo Horizonte & MG & 110 \\
\hline Brazilian Reinsurance Institute & 1943 & Rio de Janeiro & RJ & 32 \\
\hline Grande Hotel Pampulha & 1944 & Belo Horizonte & MG & 55 \\
\hline Santa Rosa square & 1945 & Belo Horizonte & MG & 174 \\
\hline Vereda Park & 1945 & Belo Horizonte & MG & 114 \\
\hline Residence of Odete Monteiro & 1948 & Petrópolis & $\mathrm{RJ}$ & 104 \\
\hline Residence of Alberto Kronsfoth & 1948 & Petrópolis & RJ & 86 \\
\hline Residence Olívio Gomes & 1950 & São Jose dos Campos & SP & 119 \\
\hline Garden terrasse of the Nova Cintra - PG & 1954 & Rio de Janeiro & $\mathrm{RJ}$ & 28 \\
\hline Ground floor of the Nova Cintra - PG & 1954 & Rio de Janeiro & RJ & 36 \\
\hline Pedregulho Housing Estate- JE & 1955 & Rio de Janeiro & RJ & 27 \\
\hline Ibirapuera Park - SB & 1956 & São Paulo & SP & 20 \\
\hline Gardens of the Museum of Modern Art & 1956 & Rio de Janeiro & RJ & 37 \\
\hline Aterro do Flamengo & 1960 & Rio de Janeiro & RJ & 203 \\
\hline
\end{tabular}

*Number of used species per project; 'PG - Guinle Park; JE - School gardens; SB - Sector of Biennial Exposition Site. State: PE - Pernambuco, RJ - Rio de Janeiro, MG - Minas Gerais, SP - São Paulo

The specimen sampling in distinct Brazilian biomes and his work with multiplication, domestication, hybridization and conservation enabled the assembly of a collection, today preserved at the "Sítio Roberto Burle Marx", which counts about 3,500 (three thousand five hundred) cultivated specimens. The group of herbaceous plants and shrubs, grown in greenhouses and in open air, make up 56 families, 206 genera and 663 species, with an emphasis on the families Araceae, Begoniaceae, Musaceae, Marantaceae, Bromeliaceae and Velloziaceae. Regarding the group of trees and species of the family Areacaceae, there are 50 families, 175 genera and 243 species (Dias 2011)

While studying Burle Marx's projects, we found a total of 1,827 botanical entities being used. Out of these, 70 are have not been identified as they present only the name of the genus or a more general name for the entity, not belonging to any taxonomic hierarchy. Identified species: 848 ; native species: 378 ; new species: 45 ; species on lists of endangered species: 41 ; species used in more than five landscaping projects: 62; native species most used in projects: 30 .

When taking the United States into consideration, as being the world's most powerful nation with a high level of technological development, including technology for the agricultural sector, and also considering the small biodiversity of North America, the conservation work and the use of genetic resources achieved by that country is noteworthy. The United States developed the National Plant Germplasm System (NPGS) through a cooperative effort between Federal and State public organizations and private organizations, besides funding by the US Department of Agriculture.

Within this system, the organization responsible for coordinating research and conservation activities for ornamental species is the Ornamental Plant Germplasm Center (OPGC), based on the Ohio State University, which has 966 accessions of 62 plant genera, a collection that is used for research and to provide support to the ornamental plant market. Since 2001, the Center has given priority to research with the following genera: Aglaonema, Alstroemeria, Anthurium, Aquilegia, Aster, Baptisia, Begonia, Campanula, Chrysanthemum, Dianthus, Dieffenbachia, Euphorbia/Poinsettia, Geranium, Hemerocallis, Impatiens, Iris, Lilium, Narcissus, Pelargonium, Petunia, Phalaenopsis, Philodendron, Phlox, Rudbeckia, Salvia, Spathiphyllum, Tagetes, Verbena, Veronica, Viola and Coreopsis (Tay 2005).

In Brazil, without a coordination of conservation activities, there are germplasm collections of ornamental species distributed in 12 institutions: the Botanic Gardens of Rio de Janeiro (JBRJ), the Brazilian Research Enterprise - National Center for Genetic Resources (Embrapa 
Cenagen), the Agency for Agro-business Technology of São Paulo (APTA), the Federal Rural University of Pernambuco (UFRPE), the State University of Santa Cruz (UESC), the Federal University of Bahia (UFBA), the State University of Feira de Santana (UEFS), the Agronomical Institute of Campinas (IAC), the Brazilian Research Enterprise for Tropical Agro-Industry (Embrapa Agroindústia Tropical), the State University of Norte Fluminense (UENF), and the Brazilian Research Enterprise for the Eastern Amazon (Embrapa Amazônia Oriental). These institutions taken as a whole house 34 Active Germplasm Banks that conserve a total of 3,759 accessions, representing the following families: Bromeliaceae, Cactaceae, Araceae, Costaceae, Marantacea, Zingiberaceae, Arecaceae, Orchidaceae, Strelitziaceae e Cycadaceae (Mariante et al. 2008).

Put into this perspective, the collection organized by Roberto Burle Marx, preserved at the Sítio Roberto Burle Marx, totalizing 106 families, 381 genera and 806 species, surpasses by several orders of magnitude the data available to the official collections, both American and Brazilian. It is a collection of great value for plant conservation, as well as for the genetic innovation of such dynamic and promising sector as landscaping and ornamental plants.

\section{FINAL CONSIDERATIONS}

It is important to mention that, seeing that there are about 500 thousand known angiosperm species in the world, from early days on, only a quite small part of this diversity, about 25 species, has become popular as food.

Burle Marx stood up for the importance of the natural riches existing all over the country in terms of landscapes, as well as products/species that are valuable both for their uniqueness and for drawing people's attention to the importance of nature. The texts written by him also addressed the importance of a responsible use of biomes, aiming at an appropriate use of our diversity and its potential for ecotourism and landscaping.

This reverberates up to the present day, seeing that, within the diverse areas where he was active, he introduced the preservation and sustainable use of biodiversity to a national debate, anticipating in decades what would happen at the
Rio Earth Summit, which took place in Rio de Janeiro, in 1992, where the Convention on Biological Diversity was established (CDB 2000, Marx 2004, Santos et al. 2009).

Therefore, looking at Burle Marx as a researcher, entrepreneur, conservationist and activist - besides considering the methods of sampling and managing germplasm he developed, enabling their conservation through use - is glimpsing a future to transform biodiversity in ornamental genetic resources. To achieve this, it will be necessary to engage in programs for genetic resources / biodiversity / conservation, associated to bio-prospection and management of plant genetic resources. Furthermore, this will allow us to identify alternatives for production and valuation of local biodiversity in order to establish a virtuous circle.

When thinking over the transformation of biodiversity in genetic resources of ornamental plants, Burle Marx offers a rich scenario for plant breeders since he opens up a series of perspectives for a work with broad possibilities for genetic innovation.

The results show that 2,019 plant species were studied, many of which, if not all, preserved by Burle Marx, seeing that he often claimed having over 3,500 preserved species. This shows that an enormous effort has been undertaken in the country regarding sampling and conservation. Part of this collection is preserved at Sítio Roberto Burle Marx, which is part of the National Institute of Historic and Artistic Heritage, belonging to the Ministry for Culture. Nonetheless, for the sake of a better use of this germplasm, there is a need for cooperative efforts between Federal and State public organizations and private organizations.

All this undertaken effort will serve as groundwork, providing support for the conservation of species, and for the fulfillment of international agreements signed by the country. It will also enhance the basic material for plant breeding, which is the preserved germplasm, providing support to obtain varieties, as well as creating new job opportunities. From the viewpoint of genetic diversity, the plant material kept by Burle Marx is an important basis for works with reduction of genetic vulnerability, and with increase of productivity, besides contributing to landscaping and ornamental plants, regarding research projects and commercial activities.

\section{Biodiversidade brasileira para uso ornamental e conservação}

Resumo - A exuberância da flora brasileira é motivo de admiração desde os primeiros navegadores. O país possui entre 15 e $20 \%$ das espécies vegetais estimadas para o planeta. Os recursos genéticos vegetais, ou seja, a fração da biodiversidade com potencial de uso pela população humana, estão ligados à cultura do povo, fixando o uso tradicional ou passando a ter uso inovador. No Brasil, o paisagista Roberto Burle Marx (RBM) foi pioneiro em utilizar, valorizar e conservar essas espécies nativas, admiradas nos séculos XVI XVI, mas desprezadas nos séculos seguintes em função da valorização das plantas ornamentais vindas da Europa. Entre 1930/1960, 
Burle Marx executou 27 projetos paisagísticos, destes, 22 foram estudados. A análise desses projetos revelam números significativos em termos de conservação da biodiversidade e domesticação de plantas.

Palavras-chave: Recursos genéticos vegetais, paisagismo, inovação genética.

\section{REFERENCES}

Cavalcanti L and El-Dahdah F (2009) Roberto Burle Marx 100 anos: a permanência do instável. Rocco, Rio de Janeiro, 250p.

CDB (2000) Convenção sobre Diversidade Biológica. Ministério do Meio Ambiente, Brasília, 30p.

Dean W (1992) Botânica e a Política Imperial: introdução e adaptação de plantas no Brasil Colonial e Imperial. Instituto de Estudos Avançados, Universidade de São Paulo, 20p.

Dias R (2011) O jardim do menino. Imprensa Oficial do Rio de Janeiro Niterói, Rio de Janeiro, 85p.

Dourado GM (2009) Modernidade verde: jardins de Burle Marx. Editora Senac, São Paulo, 385p.

Filgueiras TS and Peixoto AL (2002) Flora e vegetação do Brasil na carta de Caminha. Acta Botânica Brasileira 16: 263-272.

Flemming L (1996) Roberto Burle Marx: um retrato. Editora Index, Rio de Janeiro, 160p.

Freyre G (2003) Sobrados e Mocambos: decadência do patriarcado rural e desenvolvimento do urbano. 3 vols., Global, São Paulo.

Frota LC (2009) Roberto Burle Marx uma experiência estética: paisagismo e pintura. Design e Editora Ltda, Rio de Janeiro, 240p.

Giacometti DC and Goedert CO (1989) Brazil's National Genetic Resources and Biotechnology Center preserves and develops valuable germplasm. Diversit 5: 8-11.

Giacometti DC (1993) Recursos genéticos de fruteiras nativas do Brasil.
In Simpósio nacional de fruteiras nativas. Embrapa-CMPMF, Cruz das Almas, p. 13-27.

Graziano TT (Coord.) (2002) Relatório do diagnóstico da produção de flores e plantas ornamentais brasileiras. Relatório Ibraflor/ APEX. CD-Room.

Hawkes JG (1982) Germplasm collection preservation, and use. In Frey KJ (Ed) Plant breeding II. Kalyani Publishers, Ludhiana, p. 57-83.

Lorenzzi H and Mello Filho LE (2001) As plantas tropicais de R. Burle Marx. Instituto Plantarum de Estudos da Flora, São Paulo, 488p.

Mariante AS, Sampaio MJA and Inglis MCV (Orgs.) (2008) Informe nacional sobre a situação dos recursos fitogenéticos para alimentação e a agricultura do Brasil. Embrapa, MAPA, Brasília, $155 \mathrm{p}$.

Martins ACI (2009) Flora brasileira história, arte e ciência. Casa da Palavra, Rio de Janeiro, 167p.

Marx RB (2004) Arte \& Paisagem: (Conferências escolhidas). Organização e comentários de José Tabacow. 2nd edn, Studio Nobel, São Paulo, 233p.

Santos NM, Carvalho MP and Filho OS (2009) Burle Marx - jardins e ecologia. Editora Senac Rio, Rio de Janeiro, 124p.

Tay D (2005) Conserving Herbaceus Ornamental Plant Germplasm. In McDonald MB and Kwong FY (Eds) Flower Seeds: biology and technology. Cabi Publishing, UK, p. 333-337.

Valls JFM (1988) Caracterização morfológica, reprodutiva e bioquímica de germoplasma vegetal. In Encontro sobre recursos genéticos. UNESPFCAV, Jabotical, p. 106-128. 